\title{
Research on the Impact of China's Athletics College Sports Management Model ${ }^{*}$
}

\author{
Jiancai Shao ${ }^{1}$, Jingjing $\mathrm{Ji}^{2}$ \\ ${ }^{1}$ Department of Physical Education, East China Institute of Technology, Nanchang City, Jiangxi Province330013, China \\ ${ }^{2}$ Department of Physical Education, nanchang Institute of Technology, Nanchang City, Jiangxi Province330013, China
}

\begin{abstract}
Our existing competitive system and the education system are largely restricted the development of university sports, only two highly coordinated, will improve the competitive level of our colleges and universities. Sports development is inseparable from education, especially during the growth process of young people, which showed the importance of basic P.E. education. Developing sport quality should not ignore the cultural qualities, even can't sacrificed the education during the improvement of athletic ability. The concept of "people-oriented" should throughout the lifelong education. Essence of sport and education combined issues related to the education system and how to further deepen the reform of university system, how the healthy development of China's college sports, sustainable development and the rapid development of the fundamental issues.
\end{abstract}

Index Terms - sports management, education system, education college

\section{The Trend of China's competetive sports development}

Since the 1980s, in order to adopt the Olympic strategy , a series of strategic of the domestic competition system were adjusted including items with National Olympic Games. Its operation is based on the characteristics of the local administrative divisions and a number of large industry, relying on local government finance and industry (actual "the Nation") grants to provide funding for their training competition for the "local" or industry compete for medals. Although the competition system mobilized the participation of high-level competitive from local and industry fields in a period of short time, under the socialist market economy after breaking local administrative division, transformation of government functions to the new environment, the shortcomings of the domestic competition system gradually exposed. In another way, our sport to society, market, industry, occupation and implementation of the "Olympic strategy" does not fit in conflict with the National Olympic Games strategy, and the results are not proportional to the input and output should cause our attention.

At present, National Games is China's largest multi-sports which involves the most extensive-field athletics who got the highest marks in Games. The National Games was held for the first time since 1959. So far, the Game has successfully held 12 sessions. After 1983, in order to promote the development of sport throughout the country, the ways of holding National Games were made major adjustment. Hosting cities also changed from the capital city Beijing to co-organized by some big cities such as Shanghai, Guangzhou and Chengdu Qinhuangdao. From this way to increase government investment in sport at all levels. In order to better implement the Olympic Games and the Olympic Games of convergence, from the Seventh National Games on, the National Games was held each year after the Olympic Games, in order to make the athletes to achieve better grades in the Olympic Games.

Everything for the Games, there is no more energy to enhance people's health. Therefore, the reform of the Games has become a central part of the reform of the competition which is a great impact on the entire sports reform. Similarly sports competition system reform, especially the competition system reform will encounter new situations and new problems that need to be overcome in practical work. As the core of competitive sports, competition system is a link to the development of sports success which need for more research

Throughout the development process of competitive sports, from the 1984 Los Angeles Olympic Games, athletes return to the Games which achieved excellent results, until the Sydney Olympics in 2000, China among the top three Olympic Games, Beijing Olympic Games and London Olympic Games even achieved better results. Our sports has made brilliant achievements in less than 20 years. Sports Industry ranked among developed countries take the lead in the sports industry, primarily relying on our Sports System strong support, in essence is a concentrated expression of the superiority of the socialist system in competitive sports. Nationwide system takes full advantage of our vast territory, large population characteristics, utilization o sports resources.

In essence, the development of sports in the 1980s focused on strengthen the system under the planned economic system, while the reform after the mid-1980s is perfect the sports system that is make some adjustments without changing the original system and operational mechanism. By Sports reforms of the 1980s, the original system's strengths and weaknesses are manifested quite prominent, so that people on the formation of the planned economy era sports system is incompatible. Sports reforms of the 1980s which aimed to development of reforms, but not primarily aimed at changing the system and operational mechanism, just make some supplement and improve on the original foundation.

In 1990s, the basic ideas and the overall goal of sports

\footnotetext{
${ }^{*}$ Fund Support: The Department of social science of Jiangxi province "eleven five" (2012) planning project stage results (project number: 11TY15)
} 
reform is to reform the existing sports system and operational mechanism, and gradually achieve two fundamental changes. They are 1) the sports system under the planned economy to the socialist market economic system to adapt changes in sports system, 2) gradually establish a modern sports development law, relying on the social operating mechanism, all-round developed, in a virtuous cycle. Because of the special position of influence and competitive sports, but also due to the management of sports is the most important and original part, the competition is the core of sports system.

Major Games mainly sponsored by the government, which made the contra version of the direction of reform and development of sports. In this way, the reform does not reflects the participation of the community. With the establishment of a socialist market economy and improvement of government separation of management from operation is an inevitable trend. By then, weather a large multi-sports competition system can be survival, it remains to be seen.

Because of the different strategies between National Games and Olympics Games, which hampered the strategic goal of competitive sports power under the nationwide system to achieve. Regional focuses local interests and honor and hope the athletes from their own provinces to achieve outstanding results in the National Games, without put the country's "Olympic strategy" on the top position.

Besides the National Games, in other major multi-sports Games, the authenticity of the athlete identification also become a problem, and changing their ages, from older to younger, and impurities are commonly in each major multi-sports, especially Youth Games, City Games and University Students Games. Governments not only spending a lot of manpower, material and financial to organize the Games, but also paying much attention to the qualification of the athletes. Because the legal system lags, to solve these problems also make management difficult.

School-based physical education is both the first step of physical education, it's also the core of the development of Sports In China, colleges and universities may set the criteria to recruit high-level college athletes, who boosts excellent athletic performance, but also a requirement of cultural grades. Breaking the boundaries of schools and cities to enroll the athletes' students. Admissions process should not affect student learning, should ensure fair admissions. Details of the admissions have strict rules and restrictions.

\section{Strengthen School Management}

As a university student at the National Sports Federations registered college athletes as well, once they are admitted to university, they are in college, during the process of getting the credits of the learning they also should be required the same as other normal college students. The school can not treat them different because of th special position Strict school management should reflect the soil in the following areas:

College athletes should be consistent with the general requirements of students learning

Implementing Complete Credit System, means the athletes can not change the teaching plans and teaching arrangements to reduce the difficulty of learning to solve the contradiction between learning and training, or even can't convert the ranking into credits. As for the school, the academic and athletic performance can't be bundled together to improve student graduation rates. Learning requirements for college athletes should be consistent with the general college requirements. According to our interview on the part of the pilot schools, at present, athletic students with outstanding athletic performance is basically to ensured that its graduates.

Athletes must be officially registered full-time students. In each semester, the elective course credit is not less than the required credits. The athletes academic management were managed in the national sports federations and the school. Athlete graduation year can generally be slightly longer than the ordinary college students but also should within the maximum graduation year that the school required.

Strict credit requirements, including two meanings: First, athletes students grades should no less than the average common students' grade. Therefore, the athletes school should create the athletes profiles, which were clearly documented for the athletes students performance. At the beginning of each school year, the school may compare the athletic student with the common students, once the average grades is lower than the common students, the athletic students can not attend various competitions represent The second, athletic students can obtain a diploma and degree certifications once they get the required credits Any athletic students, even a very good athlete student should make up the classes all by himself because of participating any competitions. Everyone should be treated equally. This will not only be able to maintain the school's academic reputation, but also good for the athlete himself which will be good promotion to remove any illusions from their minds so that they may put all our energy into the study .

In order to truly implement the science-based approach, to ensure that athletes in school to learn, there is a certain time as a guarantee, The rules from Sports Articles of Association of American college students: "Obtaining the companion is not the only goal to the athletes students, the academic study is also be guaranteed.". For example: (1) As for the athlete students, the daily training time should no more than 4 hours.(2) weekly training time should no more than 20 hours (3) One day off for one week. The school should not arrange anything related to training and physical activities, etc. The above provisions of the policy process, we may take the reference.

\section{Conclusions and Suggestions}

The combination of sports and education can solve the college sports problem in China. So that to improve the competitive level of college. And it depends on the combination of all of these sports and higher education in our 
country. Therefore, establishing a standard college sports organization, unified admission standards, strengthening school management, strict eligibility, standardization the achievement standards, strict credit requirements, rigorous training requirements are imperative. At the same time, weaken sports management functions, changing the traditional centralized state administrative vertical coordinate macro-control system to self-coordination mode of society.

\section{References}

[1] Stephen K.Figler and Gail whitaker. Sport and Play. Wm.C.Brown Publishers, 1991

[2] NCAA Student-Athlete Insurance programs National Collegiate Athletie Association. Home page:

[3] MingLi. SPorts in the Global Village: A Comparative Study of Intercollegiate in China and the United Ststes. West Virginea.1994, 405 